\title{
Comparative studies of inhibitive properties of Ficus polita and Ficus platyphylla on corrosion inhibition of mild steel in acidic medium
}

\author{
Christiana Agbenu ADAH*, Sylvester Obaike ADEJO, Joeseph Aondoaver GBERTYO, and \\ Andrew Adah OGWUCHE
}

\author{
Department of Chemistry, Benue State University, Makurdi Nigeria
}

\begin{abstract}
The menace of corrosion of steel in industries has been widely acknowledged. Analysis of oil pipeline failures in oil and gas industries in the Niger Delta area of Nigeria showed corrosion as one of the major causes of failure. Ecofriendly, cheap and renewable materials such as plant extracts have been investigated as alternative to the use of expensive synthetic chemicals which are often hazardous. In this study inhibitive properties of ethanol extracts of Ficus polita and Ficus platyphylla leaves as eco-friendly inhibitors of mild steel in $2 \mathrm{M}$ sulfuric acid solution were investigated by weight loss method at temperatures of 301, 305, 309 and $313 \mathrm{~K}$. The study has shown that both plant extracts inhibited the corrosion of mild steel in the acid medium. The inhibition efficiency $(I E)$ and surface coverage $(\theta)$ for both extracts increased with increase in concentration and temperature. This trend is suggestive of chemical adsorption. However, the leaf extract of Ficus polita showed higher IE compared to F. platyphylla. Thermodynamic parameters and apparent activation energy obtained from the studies revealed the inhibition by both plant extracts to be spontaneous, exothermic and chemisorptive, while the adsorption mechanism of both plant extracts on the steel surface aligned with the Freundlich isotherm model, F. polita fits well to Temkin and Adejo-Ekwenchi isotherm models in addition.
\end{abstract}

Keywords: steel corrosion; weight loss; thermodynamics; Ficus polita; Ficus platyphylla; adsorption model.

\section{Introduction}

Corrosion is the main cause of wear in machineries, pipelines and mild steel products in general. One or more forms of corrosion such as pitting, crevices, cracking, fatigue or intergranular are involved during corrosion of mild steel corrosion resulting in the failure of components [1]. Corrosion swigs a major part of production cost in industries. The cost of corrosion to the economy of any nation is nefarious [2]. In addition to the cost corrosion adds to environmental pollution which remains a major challenge nations have to deal with [3].

The use of corrosion inhibitors has been considered an easy and cost-effective approach to combating corrosion. Synthetic inhibitors exist and are effective but add to environmental contamination hence alternative and eco-friendly inhibitors are essential [4]. Natural products of plant origin and substances from other renewable sources have gained heightened interest by researchers as green corrosion inhibitors [5-7], because they are biodegradable [8,9], less toxic [10] and do not contain heavy metals. In the light of these, several plants extracts have been investigated and their corrosion inhibition properties are often attributed to phytochemicals present [11-14]. The active phytochemicals in plants that are effective for corrosion inhibition are those that have heteroatom in their aromatic or long carbon chain $[15,16]$. The presence of $\pi$-electrons or suitable functional groups from the inhibitor's molecule enables the transfer of charge from it to the charged metal surface (physical adsorption) or the transfer of electron from the inhibitor's molecule to vacant $d$-orbital of the metal (chemical adsorption) [1719]. Heterocyclic and phenolic compounds which contains oxygen, sulfur, nitrogen atoms, and multiple bonds in the molecules have active sites for adsorption onto metal surfaces [20,21] with decrease in efficiency following the order $\mathrm{P}>\mathrm{S}>\mathrm{N}>\mathrm{O}[3]$.

$F$. polita and $F$. platyphylla belong to the family Moraceae, and genus Ficus. Several species of Ficus have shown excellent percentage inhibition efficiency [22, 23] on mild steel. Usman and coworkers [24] reported tannins, flavonoids, phlobatannins, terpenoids as present in Ficus polita. Kubmarawa et al. [25] and Akesa and team [26] reported tannins, saponins, flavonoids, glycosides, volatile oils and steroids as present in Ficus platyphylla. These tropical plants grow naturally in virgin lands in Benue State and serve mainly for shade in areas where they are planted. This work is aimed at investigation and comparison of the corrosion inhibition efficiency $F$. polita and $F$. platyphylla on mild steel in acidic medium using the weight loss method.

\section{Experimental}

\subsection{Materials and reagents}

$F$. polita and $F$. platyphylla leaves were obtained from the Main Campus of Benue State University, and identified by the Botanist, in Department of Biological Science, Benue State Makurdi-Nigeria.

Mild steel coupons ( $3 \times 4$ flat bar low carbon mild steel China) were obtained from the Engineering

\footnotetext{
* Corresponding author. E-mail address: christieadah5@gmail.com (Christiana Agbenu Adah)
} 
Department University of Agriculture Makurdi.

The reagents were purchased from Guangdong Guanghua Sci Tech China (absolute ethanol, $\mathrm{C}_{2} \mathrm{H}_{5} \mathrm{OH}$ 99.7\%; sulfuric acid, $\mathrm{H}_{2} \mathrm{SO}_{4} 98 \%$ ) and $\mathrm{BDH}$ Chemicals Ltd., England (acetone, $\mathrm{C}_{3} \mathrm{H}_{6} \mathrm{O} 99.5 \%$ ).

\subsection{Methods}

The fresh samples of $F$. polita and $F$. platyphylla leaves were washed to remove dirt and sand particles, shade dried and reduced to powder. $20 \mathrm{~g}$ of the sample were extracted by cold maceration in $200 \mathrm{~mL}$ of $\mathrm{C}_{2} \mathrm{H}_{5} \mathrm{OH}$ for 48 hours. The filtrate was separated from the residues over cotton wool and concentrated at $321 \mathrm{~K}$ in a thermostat water bath (Clifton, Nickel-Electro Ltd., England) to remove the solvent. The extract was then kept in a desiccator to avoid contamination. Stock solutions of $0.1,0.2,0.3,0.4$ and $0.5 \mathrm{~g} \cdot \mathrm{dm}^{-3}$ in $2 \mathrm{M}$ $\mathrm{H}_{2} \mathrm{SO}_{4}$ were prepared preceding the analysis. Coupons of dimensions $1.8 \mathrm{~cm} \times 2.0 \mathrm{~cm} \times 0.03 \mathrm{~cm}$ were prepared from a sample of mild steel of composition by weight (\%) Fe (98.84), Mn (0.70), P (0.04), C (0.18), Si (0.40) and $\mathrm{S}(0.40)$. Each coupon was weighed and degreased in acetone, dried and preserved in a desiccator prior to the experiment.

Previously prepared mild steel coupons were suspended without plant extracts (blank) and with plant extracts in varying concentrations of the extracts at varying temperatures ( 301 to $313 \mathrm{~K}$ ) in the water bath for 6 hours as reported by Wang et al. [18] and Adejo et al. [27], with slight modifications. The reaction of each coupon was quenched in a saturated solution of $\mathrm{CH}_{3} \mathrm{COONa}$, washed in distilled water and dried in acetone and then re-weighed after cooling. The difference in weight was used to calculate the inhibition efficiency and surface coverage $(\theta)$ through Equations 1 and 2 , respectively $[23,28]$ :

$$
\begin{aligned}
& I E(\%)=1-\frac{W 1}{W 2} \times 100 \\
& \theta=1-\frac{W 1}{W 2}
\end{aligned}
$$

where $W_{1}$ is weight of the coupon in the absence and $W_{2}$ weight of the coupon in the presence of plant extracts, respectively.

\section{Results and discussion}

\subsection{Inhibition efficiency and surface coverage}

The inhibition efficiency and surface coverage were calculated using Equations 1 and 2 respectively by substituting the weight loss data in the absence and presence of the plant extracts. Table 1 and Table 2 show inhibition efficiency and surface coverage of the green corrosion inhibitors on mild steel in $2 \mathrm{M} \mathrm{H}_{2} \mathrm{SO}_{4}$ at varying temperatures and concentrations. Inhibition efficiency and surface coverage increased with increase in inhibitor concentration and rise in temperature (K). The increase in IE with rise in temperature is suggestive of chemisorption and consistent with the work reported by [29-31]. As temperature rises, more adsorbate forms chemical bond with the metal surface thereby inhibiting corrosion. Ficus polita leaf extract showed higher surface coverage and $I E$ compared to $F$. platyphylla leaf extract. This may be due to the large quantity of phytol
(23.3\%); 6, 10, 14-trimethyl-2-pentadecanone (15.0\%); (E)-6, 10-dimethyl-5, 9-undecadien-2-one $(7.3 \%)$ and drimenol (5.8\%), sesquiterpenes ( $\alpha$-yiangene, $\alpha$ copaene), $\gamma$-cadienee, $(E, E)$ - $\alpha$-farnesene in $F$. polita [32]. Although $F$. platyphylla contains volatile oils, terpenoids are absent. Terpenoids are highly conjugated and electron rich compounds which may provide more adsorption sites. This difference in their chemical composition may account for the higher inhibition efficiency observed with $F$. polita. However, reasoning is still open to speculations.

Table 1. Variation of $I E$ and $\theta$ of Ficus polita leaf extract with concentration and temperature

\begin{tabular}{lcccccccc}
\hline $\begin{array}{l}\text { Conc. } \\
\mathbf{g} \cdot \mathbf{d m}^{-\mathbf{3}}\end{array}$ & \multicolumn{3}{c}{$\begin{array}{c}\text { Inhibition efficiency } \\
(\boldsymbol{I} \boldsymbol{E} \boldsymbol{\%})\end{array}$} & \multicolumn{4}{c}{$\begin{array}{c}\text { Surface coverage } \\
(\boldsymbol{\theta})\end{array}$} \\
\hline $\boldsymbol{T}[\boldsymbol{K}]$ & $\mathbf{3 0 1}$ & $\mathbf{3 0 5}$ & $\mathbf{3 0 9}$ & $\mathbf{3 1 3}$ & $\mathbf{3 0 1}$ & $\mathbf{3 0 5}$ & $\mathbf{3 0 9}$ & $\mathbf{3 1 3}$ \\
0.1 & 17.77 & 19.13 & 22.30 & 27.80 & 0.1777 & 0.1913 & 0.2230 & 0.2780 \\
0.2 & 23.42 & 25.83 & 27.70 & 30.04 & 0.2342 & 0.2583 & 0.2770 & 0.3004 \\
0.3 & 26.96 & 28.66 & 30.95 & 33.50 & 0.2696 & 0.2866 & 0.3095 & 0.3350 \\
0.4 & 36.96 & 39.21 & 43.24 & 46.14 & 0.3696 & 0.3921 & 0.4324 & 0.4614 \\
0.5 & 45.82 & 48.98 & 53.85 & 55.96 & 0.4582 & 0.4898 & 0.5385 & 0.5596 \\
\hline
\end{tabular}

Table 2. Variation of IE and $\theta$ of $F$. platyphylla leaf extract with concentration and temperature

\begin{tabular}{lccccccccc}
\hline $\begin{array}{l}\text { Conc. } \\
\mathbf{g} \cdot \mathbf{d m}^{-3}\end{array}$ & \multicolumn{3}{c}{$\begin{array}{c}\text { Inhibition efficiency } \\
(\boldsymbol{I} \boldsymbol{E} \boldsymbol{\%})\end{array}$} & \multicolumn{5}{c}{$\begin{array}{c}\text { Surface coverage } \\
(\boldsymbol{\theta})\end{array}$} \\
\hline $\boldsymbol{T}[\boldsymbol{K}]$ & $\mathbf{3 0 1}$ & $\mathbf{3 0 5}$ & $\mathbf{3 0 9}$ & $\mathbf{3 1 3}$ & $\mathbf{3 0 1}$ & $\mathbf{3 0 5}$ & $\mathbf{3 0 9}$ & $\mathbf{3 1 3}$ \\
0.1 & 1.65 & 3.13 & 6.22 & 8.41 & 0.0165 & 0.0313 & 0.0622 & 0.0841 \\
0.2 & 3.31 & 5.00 & 10.52 & 13.38 & 0.0331 & 0.0500 & 0.1052 & 0.1338 \\
0.3 & 6.43 & 10.83 & 12.59 & 18.03 & 0.0643 & 0.1083 & 0.1259 & 0.1803 \\
0.4 & 13.60 & 18.96 & 19.26 & 23.57 & 0.1360 & 0.1896 & 0.1926 & 0.2357 \\
0.5 & 23.71 & 25.00 & 30.74 & 35.10 & 0.2371 & 0.2500 & 0.3074 & 0.3510 \\
\hline
\end{tabular}

3.2. Calculated values of activation energy and heat of adsorption

The apparent activation energy $\left(E_{\mathrm{a}}\right)$ was calculated from the Arrhenius equation given as [22, 33]:

$$
\log C_{R}=\log A-\left(\frac{E_{a}}{2.303 R T}\right)
$$

$E_{\mathrm{a}}$ was obtained from the slope of the plot of $\log C_{\mathrm{R}}$ against $1 / T$, where $C_{\mathrm{R}}$ is corrosion rate $\left(\mathrm{mg} / \mathrm{cm}^{2} \cdot \mathrm{h}\right), A$ is the constant frequency factor, $E_{\mathrm{a}}$ is the apparent activation energy, $R$ is molar gas constant and $T$ is absolute temperature. The values of heat of adsorption $\left(Q_{a d s}\right)$ were obtained from the slope $\mathrm{Q}_{\text {ads }} / 2.303 \mathrm{R}$ of the plot of $\log \theta / 1-\theta$ against $1 / \mathrm{T}$.

Tables 3 and 4 show the data for activation energy $\left(E_{\mathrm{a}}\right)$ and thermodynamic properties $\left(Q_{\mathrm{ads}}, \Delta H, \Delta S\right.$ and $\Delta G$ ) for the process of corrosion inhibition of extracts of Ficus polita and Ficus platyphylla respectively. The apparent activation energy $\left(E_{\mathrm{a}}\right)$ of the inhibition process decreased with increasing inhibitor concentration. Values of activation energy in physisorption process are lower than $40 \mathrm{~kJ} / \mathrm{mol}$, while higher than this limit is chemisorption [33]. This implies that the green inhibitors are adsorbed to the surface of the metal by chemical bonding.

\subsection{Thermodynamic properties}

The enthalpies $(\Delta H)$ of adsorption of both plant extracts decreased with increase in inhibitor concentration, the strength of the adsorption increased with increase in the concentration of the inhibitor indicative of interaction between the metal surface and the inhibitors [27]. The values of heat of adsorption for both $F$. polita and $F$. platyphylla extracts were positive implying that both 
processes are endothermic and did take up energy from the surrounding. The Gibb's free energy is negative implying spontaneity of the adsorption reactions. It is also important to note that values of Gibb's free energy of adsorption, greater than $-40 \mathrm{~kJ} / \mathrm{mol}$ are consistent with the transfer of electron from the inhibitor to the metal surface which represents a chemical adsorption whereas, values of Gibb's free energy less than -40 $\mathrm{kJ} / \mathrm{mol}$ signifies the mechanism of physical adsorption [34]. This confirms further the mechanism of adsorption of both green inhibitors is chemisorption as the values of the Gibb's free energy are greater than $-40 \mathrm{~kJ} / \mathrm{mol}$.

Table 3. Activation energy $\left(\mathrm{E}_{\mathrm{a}}\right)$ and thermodynamic parameters $\left(\Delta H, \Delta S\right.$ and $\left.\Delta G_{\text {ads }}\right)$ of $F$. polita leaf extract inhibition process

\begin{tabular}{lcccccccc}
\hline $\begin{array}{c}\text { Conc. } \\
\mathrm{g} \cdot \mathrm{dm}^{-3}\end{array}$ & $\begin{array}{c}E_{\mathrm{a}} \\
(\mathrm{kJ} / \mathrm{mol})\end{array}$ & $\begin{array}{c}\Delta \mathrm{H} \\
(\mathrm{kJ} / \mathrm{mol})\end{array}$ & $\begin{array}{c}\Delta \mathrm{S} \\
(\mathrm{J} / \mathrm{K})\end{array}$ & $\begin{array}{c}- \text { Qads } \\
(\mathrm{kJ} / \mathrm{mol})\end{array}$ & \multicolumn{3}{c}{$\begin{array}{c}\Delta \mathrm{G}_{\text {ads }} \\
(\mathrm{kJ} / \mathrm{mol})\end{array}$} \\
\hline Blank & 75.54 & 73.04 & 209.38 & - & 301 & 305 & 309 & 313 \\
0.1 & 70.30 & 67.79 & 366.24 & 25.24 & 21.72 & 24.14 & 29.61 & 40.24 \\
0.2 & 70.45 & 67.94 & 366.08 & 18.80 & 15.56 & 17.73 & 19.77 & 22.44 \\
0.3 & 70.06 & 67.55 & 364.41 & 18.04 & 12.37 & 13.64 & 15.42 & 17.55 \\
0.4 & 65.75 & 63.24 & 348.87 & 42.14 & 14.73 & 16.42 & 19.65 & 22.38 \\
0.5 & 62.35 & 59.84 & 336.31 & 25.74 & 17.00 & 19.55 & 24.08 & 26.56 \\
\hline
\end{tabular}

Table 4. Activation energy and thermodynamic parameters

( $Q_{\text {ads }}, \Delta H, \Delta S$ and $\Delta G_{\text {ads }}$ ) of $F$. platyphylla leaf extract inhibition process

\begin{tabular}{lllllcccc}
\hline $\begin{array}{c}\text { Conc. } \\
\mathrm{g} \cdot \mathrm{dm}^{-3}\end{array}$ & $\begin{array}{l}E_{\mathrm{a}} \\
(\mathrm{kJ} / \mathrm{mol})\end{array}$ & $\begin{array}{l}\Delta \mathrm{H} \\
(\mathrm{kJ} / \mathrm{mol})\end{array}$ & $\begin{array}{l}\Delta \mathrm{S} \\
(\mathrm{J} / \mathrm{K})\end{array}$ & $\begin{array}{l}-\mathrm{Q}_{\text {ads }} \\
(\mathrm{kJ} / \mathrm{mol})\end{array}$ & \multicolumn{4}{c}{$\begin{array}{c}\Delta \mathrm{G}_{\text {ads }} \\
(\mathrm{kJ} / \mathrm{mol})\end{array}$} \\
\hline Blank & 67.19 & 66.60 & 362.00 & - & 301 & 305 & 309 & 313 \\
0.1 & 62.18 & 61.79 & 346.39 & 117.19 & 1.686 & 3.290 & 6.843 & 9.597 \\
0.2 & 59.40 & 56.91 & 329.33 & 106.28 & 1.720 & 2.680 & 6.065 & 8.072 \\
0.3 & 58.83 & 56.32 & 327.00 & 73.06 & 2.302 & 4.123 & 4.953 & 7.663 \\
0.4 & 60.14 & 57.63 & 330.66 & 39.33 & 3.955 & 5.956 & 6.153 & 8.057 \\
0.5 & 55.98 & 54.40 & 323.70 & 38.77 & 6.247 & 6.789 & 9.159 & 11.305 \\
\hline
\end{tabular}

\subsection{Adsorption isotherms}

The linearized forms of the isotherms studied are given in the equations below $[35,36]$ :

Langmuir: $\quad \frac{C}{\theta}=\frac{1}{K}+C$

Freundlich: $\log \theta=\log K_{F}+n_{F} \log C$

Temkin: $\quad \frac{-2 \alpha \theta}{2.303}=\log k+\log C$

$$
\text { El-Awady: } \quad \log \frac{\theta}{(1-\theta)}=\log K+y \log [C]
$$

Adejo- Ekenchi: $\log \frac{1}{1-\theta}=\log K_{A E}+b \log C(8$

where $\theta$ is surface coverage, $K$ is corrosion rate constant, $n_{\mathrm{F}}$ is Freunlich constant, the parameter $\alpha$ indicates the type of interaction at adsorbent surface, $y$ is number of water molecules replaced by corrosion inhibitor in ElAwady isotherm, $b$ is slope, and $K_{\mathrm{AE}}$ is the AdejoEkwenchi adsorption constant.

The data for adsorption isotherms shown in Table 5 for Langmuir, Freundlich, El-Awady, Temkin and Adejo-Ekwenchi isotherms were employed to study the adsorption mechanism of $F$. polita. The values of the equilibrium constants $\left(K_{\text {ads }}\right)$ were all positive, indicative of favorable adsorption. The $R^{2}$ values of Langmuir isotherm is a bit far less than unity thus the adsorption cannot be modeled by this isotherm. The $R^{2}$ values in Freundlich isotherm are close to unity and also the values of $n$ parameter are close to the typical value of 0.6 [27] and thus these data can be modeled by this isotherm. The fitting of the adsorption into Temkin isotherm model confirms further the chemical adsorption mechanism of the inhibitor onto the metal surface. The negative values of the $\alpha$ parameter is indicative of repulsive interaction of the molecules within the layer of adsorption. Temkin isotherm model fitting is a feature of chemisorption [37]. For El-Awady isotherm, values of $y>1$ implies a multilayer formation and values of $y<1$ implies monolayer, that is an inhibitor occupies more than one active site. The values of $y$ from this study were less than one indicative of mono layer formation and confirming further chemisorption adsorption mechanism $[27,38]$. The $b$ parameter in the Adejo-Ekwenchi isotherm is useful in resolving the mechanism of adsorption. Values of parameter $b$ decreasing with rise in temperature shows physical adsorption and increase or fairly constant $b$ value with increase in temperature indicates chemisorption. The value of $b$ in this study increases with increase in temperature which signifies chemical adsorption mechanism [39].

Table 5. Adsorption isotherm parameters for adsorption of $F$. polita leaf extract onto the mild steel surface

\begin{tabular}{|c|c|c|c|c|c|c|c|}
\hline Isotherm & $\begin{array}{c}T \\
{[\mathrm{~K}]} \\
\end{array}$ & $R^{2}$ & Slope & Intercept & $K_{\text {ads }}$ & & $-\Delta G_{\text {ads }}$ \\
\hline \multirow[t]{5}{*}{ Langmuir } & 301 & 0.7741 & 1.2666 & 0.5410 & 1.8484 & & 11.5889 \\
\hline & 305 & 0.7486 & 1.2420 & 0.5043 & 1.9829 & & 11.9206 \\
\hline & 309 & 0.7103 & 1.1633 & 0.4497 & 2.2237 & & 12.3713 \\
\hline & 313 & 0.7710 & 1.1513 & 0.4023 & 2.4857 & & 12.8213 \\
\hline & & & & & & $n$ & \\
\hline \multirow[t]{5}{*}{ Freundlich } & 301 & 0.9484 & 0.5749 & -0.1999 & 0.6311 & 0.5749 & 8.8992 \\
\hline & 305 & 0.9314 & 0.5561 & -0.1883 & 0.6482 & 0.5561 & 9.0855 \\
\hline & 309 & 0.8934 & 0.5247 & -0.1638 & 0.6858 & 0.5247 & 9.3495 \\
\hline & 313 & 0.9114 & 0.5102 & -0.1431 & 0.7193 & 0.5102 & 9.5944 \\
\hline & & & & & & $-\alpha$ & \\
\hline \multirow[t]{5}{*}{ Temkin } & 301 & 0.8739 & 0.3830 & 0.5319 & 1.7022 & 0.0833 & 11.3830 \\
\hline & 305 & 0.8531 & 0.3900 & 0.5538 & 1.7399 & 0.0856 & 11.5893 \\
\hline & 309 & 0.8169 & 0.4180 & 0.6004 & 1.8228 & 0.0908 & 11.8607 \\
\hline & 313 & 0.8407 & 0.4300 & 0.6305 & 1.8785 & 0.0934 & 12.0926 \\
\hline & & & $y$ & & & & \\
\hline \multirow[t]{5}{*}{ El-Awady } & 301 & 0.9201 & 0.8192 & 0.1076 & 1.3532 & & 10.8082 \\
\hline & 305 & 0.8979 & 0.8146 & 0.1382 & 1.4780 & & 11.1754 \\
\hline & 309 & 0.8529 & 0.8167 & 0.2050 & 1.2859 & & 10.9644 \\
\hline & 313 & 0.8708 & 0.8207 & 0.2530 & 2.0365 & & 12.3026 \\
\hline & & & $b$ & & & & \\
\hline \multirow[t]{4}{*}{$\begin{array}{l}\text { Adejo- } \\
\text { Ekwenchi }\end{array}$} & 301 & 0.8343 & 0.2443 & 0.3074 & 2.0296 & & 11.8227 \\
\hline & 305 & 0.8096 & 0.2585 & 0.3265 & 2.1208 & & 12.0911 \\
\hline & 309 & 0.7701 & 0.2921 & 0.3692 & 2.3399 & & 12.5021 \\
\hline & 313 & 0.7926 & 0.3106 & 0.3967 & 2.4929 & & 12.8288 \\
\hline
\end{tabular}

Table 6 shows the fitting of data into various adsorption isotherms for the $F$. platypylla leaf extract onto the mild steel surface. The $R^{2}$ values show that the adsorption data fit into Freundlich isotherm. The equilibrium constants $\left(K_{\text {ads }}\right)$ were positive implying favorable adsorption. Although the $R^{2}$ values of Freundlich isotherm are close to unity, the $n$ parameter is greater than 0.6 [40]. The $y$ values for El-Awady isotherm are greater than 1 which implies the reaction forms multilayer suggesting physical adsorption 
mechanism, hence the data does not fit into this isotherm.

Table 6. Adsorption isotherm parameters for adsorption of $F$. platypylla leaf extract onto the mild steel surface

\begin{tabular}{cccccccc}
\hline Isotherm & $\begin{array}{c}\boldsymbol{T} \\
{[\mathbf{K}]}\end{array}$ & $\boldsymbol{R}^{\mathbf{2}}$ & Slope & Intercept & $\boldsymbol{K}_{\text {ads }}$ & & $-\boldsymbol{G}_{\text {ads }}$ \\
\hline \multirow{4}{*}{ Freundlich } & & & & & & $n$ & \\
& 301 & 0.9544 & 1.6407 & 0.2305 & 1.7002 & 1.6407 & 11.38 \\
& 305 & 0.9552 & 1.3484 & 0.2313 & 1.7033 & 1.3484 & 11.54 \\
& 309 & 0.9309 & 0.9195 & 0.3251 & 2.1140 & 0.9195 & 12.24 \\
& 313 & 0.9598 & 0.8107 & 0.2731 & 1.8754 & 0.8107 & 12.09 \\
\hline \multirow{4}{*}{ Temkin } & & & & & & $-\alpha$ & \\
& 301 & 0.7362 & 0.1223 & 0.2619 & 1.2994 & 0.0612 & 10.71 \\
& 305 & 0.8408 & 0.1339 & 0.3060 & 1.3580 & 0.0670 & 10.96 \\
& 309 & 0.7718 & 0.1320 & 0.3363 & 1.3998 & 0.0660 & 11.18 \\
& 313 & 0.8323 & 0.1461 & 0.3960 & 1.4859 & 0.0731 & 11.48 \\
\hline \multirow{5}{*}{ El-Awady } & 301 & 0.9419 & 1.7793 & 0.1032 & 1.1429 & & 10.39 \\
& 305 & 0.9474 & 1.5031 & 0.0805 & 1.1312 & & 10.50 \\
& 309 & 0.9077 & 1.0799 & 0.1540 & 1.3887 & & 11.16 \\
& 313 & 0.9358 & 0.9963 & 0.0650 & 1.1620 & & 10.84 \\
\hline
\end{tabular}

\section{Conclusions}

Ethanol leaf extracts of $F$. polita and $F$. platyphylla were investigated for their corrosion inhibition properties onto the surface of mild steel in acidic medium, with $F$. polita showing higher inhibition efficiency than $F$. platyphylla. The chemisorption adsorption mechanism of $F$. polita best fit Freundlich, Temkin and AdejoEkwenchi isotherm models, while chemisorption mechanism of $F$. platyphylla fits well Freundlich adsorption isotherm model.

\section{Acknowledgements}

We appreciate the Botanist, Mr. Waya for helping with identification of the plants.

\section{Conflict of interest}

Authors declare no conflict of interest.

\section{References}

[1]. L.T. Popoola, A.S. Grema, G.K. Latinwo, B. Gutti, A.S. Balogun, Corrosion problems during oil and gas production and its mitigation, International Journal of Industrial Chemistry 4 (2013) e 35.

[2]. D. Kesavan, M. Gopiraman, N. Sulochana Green inhibitors for corrosion of metals: A review, Chemical Science Review and Letters 1 (2012) 18.

[3]. S.O. Adejo, S.G. Yiase, L. Leke, M. Onuche, M.V. Atondo, T.T. Uzah, Corrosion studies of mild steel in sulphuric acid medium by acidimetric method, International Journal of Corrosion Scale Inhibition 8 (2019) 50-61.

[4]. H. Wei, B. Heidarshenas, L. Zhou, G. Hussain, Q. Li, K.K. Ostrikov, Green inhibitors for steel corrosion in acidic environment: State-of-art, Materials Today Sustainability 10 (2020) 100044. https://doi.org/10.1016/j.mtsust.2020.100044
[5]. M. Bendahou, M. Benabdellah, B. Hammouti, A study of rosemary oil as a green corrosion inhibitor for steel in $2 \mathrm{M} \mathrm{H}_{3} \mathrm{PO}_{4}$, Pigment and Resin Technology 35 (2006) 95-100. http://dx.doi.org/10.1108/03699420610652386.

[6]. C. Verma, E.E. Ebenso, I. Bahadur, M.A. Quraishi, Sulfur and phosphorus heteroatom-containing compounds as corrosion inhibitors: An overview, Heteroatom Chemistry 29 (2018) e21437. https://doi.org/10.1002/hc.21437

[7]. C. Verma, E.E. Ebenso, I. Bahadur, M.A. Quraishi, An overview on plant extracts as environmental sustainable and green corrosion inhibitors for metals and alloys in aggressive corrosive media, Journal of Molecular Liquids. 266 (2018) 577-590. https://doi.org/10.1016/j.molliq.2018.06.110

[8]. S. Marzorati, L. Verotta, S.P. Trasatti, Green corrosion inhibitors from natural sources and biomass wastes, Molecules 24 (2019) 48. https://doi.org/10.3390/molecules24010048

[9]. P.C. Okafor, M.E. Ikpi, I.E. Uwah, E.E. Ebenso, U.J. Ekpe, S.A Umoren, Inhibitory action of Phyllanthus amarus extracts on the corrosion of mild steel in acidic media, Corrosion Science 50 (2008) 2310-2317.

[10]. U.J. Ahile, S.O. Adejo, J.A. Gbertyo, F.F. Idachaba, R.L. Tyohemba, S.O. Ama, Ethanol stem extract of Mucuna Pruriens as green corrosion inhibitor for corrosion of aluminium in $\mathrm{H}_{2} \mathrm{SO}_{4}$, Journal of Applied Chemistry 3 (2014) 2039-2046.

[11]. X. Li, S. Deng, H. Fu, Inhibitive effects and mechanism of phosphates on the stress corrosion cracking of brass in ammonia solutions, Corrosion Science 62 (2012) 163-175. http://dx.doi.org/10.1016/j.corsci.2012.05.008.

[12]. P.B. Raja, M.G. Sethuraman, Natural products as corrosion inhibitor for metals in corrosive media - A review, Materials Letters 62 (2007) 113-116.

[13]. N. Karthiga, S. Rajendran, P. Shanthy, A. Krishnaveni, J. Jeyasundari, R.M. Joany, A.C.C. Mary, T. Umasankareswari, Corrosion inhibition of mild steel by an aqueous extract of allium sativum, International Journal of Nano Corrosion Science and Engineering 2 (2015) 255-269.

[14]. P.R. Sivakumar and A. P. Srikanth, Green corrosion inhibitor: A comparative study, Sådhanå 45 (2020) 56. https://doi.org/10.1007/s12046-0201283-X

[15]. L.A. Nnanna, O.C. Nwadiuko, N.D. Ekekwe, C.F. Ukpabi, S.C. Udensi, K.B. Okeoma, B.N. Onwuagba, I.M. Mejeha, Adsorption and inhibitive properties of leaf extract of Newbouldia leavis as a green inhibitor for aluminium alloy in $\mathrm{H}_{2} \mathrm{SO}_{4}$, American Journal of Material Science 1 (2011) 143-148.

[16]. S.K. Sharma, A. Peter, I.B. Obot, Potential of Azadirachta indica as a green corrosion inhibitor against mild steel, aluminum, and tin: a review, Journal of Analytical Science and Technology 6 (2015) 26. https://doi.org/10.1186/s40543-0150067-0

[17]. L. H. Madkour, U.A. Zinhome, Inhibition, kinetic 
and thermodynamic effects of new azo derivatives on iron corrosion in acidic and alkaline solutions, Standard Scientific Research and Essays 2 (2014) 705-724

[18]. Q. Wang, B. Tan, H. Bao, Y. Xie, Y. Mou, P. Li, D. Chen, Y. Shi, X. Li, W. Yang, Evaluation of Ficus tikoua leaves extract as an eco-friendly corrosion inhibitor for carbon steel in $\mathrm{HCl}$ media, Biochemistry 128 (2019) 49-45.

[19]. A. Rodríguez-Torres, M.G. Valladares-Cisneros, C. Cuevas-Arteaga, M.A. Veloz-Rodríguez, Study of green corrosion inhibition on AISI 1018 carbon steel in sulfuric acid using Crataegus mexicana as eco-friendly inhibitor, Journal of Materials and Environmental Sciences 10 (2019) 101-112.

[20]. A. Singh, E.E. Ebenso, M.A. Quraishi, Theoretical and electrochemical studies of Cuminum cyminum (Jeera) extract as green corrosion inhibitor for mild steel in hydrochloric acid solution, International Journal of Electrochemical Science 7 (2012) 85438559.

[21]. H. Lgaz, R. Salghi, I.H. Ali, Corrosion inhibition behavior of 9-hydroxyrisperidone as a green corrosion inhibitor for mild steel in hydrochloric acid: Electrochemical, DFT and MD simulations studies, International Journal of Electrochemical Science 13 (2018) 250 - 264. DOI: 10.2964/2018.01.26.

[22]. R.A. Anaee, M.H. Alzuhairi, H.A. Abdullah, Corrosion inhibition of steel in petroleum medium by Ficus carica leaves extract, Asian Journal of Engineering and Technology 2 (2014) 235-243.

[23]. M. K. Bagga, R. Gadi, O.S. Yadav, R. Kumar, R. Chopra, G. Singh, Investigation of phytochemical components and corrosion inhibition property of Ficus racemose stem extract on mild steel in $\mathrm{H}_{2} \mathrm{SO}_{4}$ medium, Journal of Environmental Chemical Engineering 4 (2016) 4699-4707.

[24]. A.U. Usman, O. O. Kaigama, A.M. Ibisagba, I. A. Fulata, J. Ahmed, Phytoconstituents evaluation and antimicrobial efficacy of the crude flavonoids and saponins rootbark extracts of Terminalia avicennioides and Ficus polita, Journal of Herbmed Pharmacology 7 (2018) 106-111. DOI: 10.15171/jhp.2018.18

[25]. D. Kubmarawa, M.E Khan, A.M. Punah, M. Hassan, Phytochemical and antimicrobial screening of Ficus platyphylla against human/animal pathogens, The Pacific Journal of Science and Technology 10 (2009) 382-386.

[26]. T.M. Akesa, D.K. Adedzwa, R.W. Anyam, S.T. Apeelu, J.I. Waya, P.T. Dughdugh, Taxonomic studies of members of the family Moraceae in selected areas of Benue State, Nigeria, Global Scientific Journal 5 (2017) 68-84.

[27]. S.O. Adejo, M.M. Ekwenchi, J.U. Ahile, J.A. Gbertyo, A. Kaior, Resolution of adsorption characterization ambuiguity through the AdejoEkwenchi adsorption isotherm: A case study of leaf extract of Hyptis suaveolen poit as green corrosion inhibitor of corrosion of mild steel in $2 \mathrm{M}$ $\mathrm{HCl}$, Journal of Emerging Trends in Engineering and Applied Sciences 5 (2014) 201-205.
[28]. M.A. Velázquez-González, J.G. GonzalezRodriguez, M.G. Valladares-Cisneros, M.G., I.A. Hermoso-Diaz, Use of Rosmarinus officinalis as green corrosion inhibitor for carbon steel in acid medium, American Journal of Analytical Chemistry 5 (2014) 55-64.

[29]. E.E. Oguzie, C.B. Adindu, C.K. Enenebeaku, C.E. Ogukwe, M.A. Chidiebere, K.L. Oguzie, Natural products for materials protection: mechanism of corrosion inhibition of mild steel by acid extracts of Piper guineense, Journal of Physical Chemistry 116 (2012) 13603-13615.

[30]. S.O. Adejo, M.M. Ekwenchi, P.O. Olatunde, E.F. Agbajeola, Adsorption characteristics of ethanol root extract of Portulaca oleracea as eco-friendly inhibitor of corrosion of mild steel in $\mathrm{H}_{2} \mathrm{SO}_{4}$ medium, IOSR Journal of Applied Chemistry 7 (2014) 55-60.

[31]. C.A. Adah, J.A. Gbertyo, G.A. Otokpa, Studies on the corrosion inhibition of ethanol extract of Newbouldia laevis stem bark and leaf on mild steel in acidic medium, Chemistry Research Journal 5 (2020) 96-103.

[32]. I.A. Ogunwande, M.A. Sonibare, T.D. Thang, N.X. Dung, M.O. Soladoye, O.O. Morohunfolu, Comparative analysis of the oils of three Ficus species from Nigeria, Journal of Essential Oil Research 20 (2011) 386-389.

[33]. V.J. Inglezakis, A.A. Zorpas, Heat of adsorption, adsorption energy and activation energy in adsorption and ion exchange systems, Desalination and Water Treatment 39 (2012) 149-157. DOI: 10/5004/dwt.2012.3000

[34]. E.O. Nnabuk, F. Awe, E.E. Ebenso, Adsorption and inhibitive properties of ethanol extracts of leaves of Solanum melongena for the corrosion of mild steel in $0.1 \mathrm{M} \mathrm{HCl}$, International Journal of Electrochemical Science 5 (2010) 1996 - 2011.

[35]. A.I. Onen, J.T. Barminas, J. Jacob, Inhibitory action of Ficus carica extracts on aluminium corrosion in acidic medium, Chemical Science Transactions 2 (2013) 1326-1333. DOI: $10.7598 /$ cst2013.558

[36]. V.G. Vasudha, P.K. Shanmuga, Polyalthia longifolia as a corrosion inhibitor for mild steel in $\mathrm{HCl}$ solution, Research Journal of Chemical Science 3 (2013) 21-26.

[37]. N. Ayawei, A.N. Ebelegi, D. Wankasi, Modelling and interpretation of adsorption isotherms, Journal of Chemistry $2017 \quad$ (2017) 3039817. https://doi.org/10.1155/2017/3039817.

[38]. E. Ituen, O. Akaranta, A. James, Evaluation of performance of corrosion inhibitors using adsorption isotherm models: An overview, Chemical Science International Journal 18 (2017) 1-34

[39]. S.O. Adejo, S.G.Yiase, J.A. Gbertyo, E. Ojah, Aspartic acid as corrosion inhibitor of mild steel corrosion using weight loss, acidimetry and EIS measurement, Journal of Advances in Chemistry 15 (2018) 6262-6274.

[40]. S.O. Adejo, M.M. Ekwenchi, J.A. Gbertyo, T. Menenge, J.O. Ogbodo, Determination of 
adsorption isotherm model best fit for methanol leaf extract of Securinega virosa as corrosion inhibitor for corrosion of mild steel in $\mathrm{HCl}$, Journal of Advances in Chemistry 10 (2014) 2737-2742.
Received: 01.09.2020

Received in revised form: 16.03.2021

Accepted: 17.03.2021 